\title{
Supplementation of Psidium guajava (Guava) Fruit Polysaccharide Attenuates Paracetamol-induced Liver Injury by Enhancing the Endogenous Antioxidant Activity
}

(Penambahan Polisakarida Buah Psidium guajava (Jambu Batu) Mengatenuasi Aruhan Parasetamol daripada Kecederaan Hepar dengan Mempertingkatkan Aktiviti Antioksida Endogenus)

\author{
ASPALILAH Alias, FAIZAH OTHMAN, ABDUl RASHID Li, AQILAH KAMARUDDIN, RAFIZUL YUSOF \& FARIDA HUSSAN*
}

\section{ABSTRACT}

This study was aimed to determine the effect of polysaccharide from guava fruit on paracetamol (PCM)-induced liver injury. Aqueous extract of Psidium guajava fruit was treated with $95 \%$ ethanol to collect the water soluble polysaccharide precipitates. Thirty-eight male Sprague Dawley rats were divided into control (C), PPG400, PCM, PPG200+PCM and $P P G 400+P C M$. The control and PCM groups received 0.9\% normal saline orally while the rest were given 200 and 400 $\mathrm{mg} / \mathrm{kg}$ of freeze-dried polysaccharide (PPG) per oral for fourteen days. At day 15, the animals were orally received $P C M$ $(2 \mathrm{~g} / \mathrm{kg})$ except the control and PPG400 groups which received 5\% dimethyl sulfoxide. At day 16, the blood was collected to determine serum liver enzymes such as transaminases (AST and ALT). The liver tissue was harvested for determination of superoxide dismutase (SOD), glutathione (GSH), tumour necrosis factor- $\alpha$ (TNF- $\alpha$ ), interleukin-6(IL6), microscopic changes and glycogen content. The PCM group showed significant higher level of AST, ALT, TNF- $\alpha$ and IL6 than those of group C. The PCM group showed glycogen depletion, vacuolisation, loss of cell membrane, inflammatory cells infiltration and distorted hepatocelluar cords and narrow sinusoidal spaces. However, those PCM-induced alterations were attenuated by the PPG supplementation. Therefore, the polysaccharide of Psidium guajava possesses hepatoprotective activity and can be used as a dietary supplementation for protection of liver.

Keywords: Antioxidant; guava; liver; paracetamol; polysaccharide

\section{ABSTRAK}

Kajian ini bertujuan untuk menentukan kesan polisakarida daripada buah jambu batu pada parasetamol (PCM) yang menyebabkan kecederaan hepar. 95\% etanol digunakan untuk mendapatkan ekstrak akueus daripada buah Psidium guajava untuk mengumpul mendakan polisakarida larut air. Tiga puluh lapan ekor tikus jantan Sprague Dawley telah dibahagikan kepada kumpulan kawalan (C), PPG400, PCM, PPG200+PCM dan PPG400+PCM. Kumpulan kawalan (C) dan PCM telah menerima $0.9 \%$ air garam secara oral manakala yang lain telah diberikan 200 dan $400 \mathrm{mg} / \mathrm{kg} \mathrm{serbuk}$ polisakarida (PPG) melalui oral dalam masa empat belas hari. Pada hari 15, semua haiwan menerima PCM (2 g/kg) secara oral kecuali kumpulan kawalan dan PPG400 menerima 5\% dimetil sulfoksid. Pada hari 16, darah diambil untuk mengetahui enzim serum hepar seperti transaminase (AST dan ALT). Tisu hepar telah diambil untuk mengetahui tahap superoksida dismutase (SOD), glutation (GSH), nekrosis tumor faktor - $\alpha$ (TNF- $\alpha$ ), interleukin -6 (IL6), perubahan mikroskopik dan kandungan glikogen. Kumpulan PCM menunjukkan tahap signifikan yang lebih tinggi pada AST, ALT, TNF- $\alpha$ dan IL6 berbanding dengan kumpulan C. Kumpulan PCM menunjukkan kekurangan glikogen, pemvakuolan, kehilangan sel membran, infiltrasi sel-sel inflamasi, perubahan pada korda hepatosel dan ruang sinusoidal mengecil. Walau bagaimanapun, apa-apa perubahan yang disebabkan PCM telah dibantu oleh suplemen PPG ini. Oleh itu, polisakarida daripada Psidium guajava mempunyai aktiviti hepatopelindung dan ia boleh digunakan sebagai suplemen pemakanan untuk perlindungan hepar.

Kata kunci: Antioksida; hepar; jambu batu; parasetamol; polisakarida

\section{INTRODUCTION}

Guava is known to possess medicinal properties and is called Jambu Batu in Malaysia. Botanically, this plant belongs to the family of Psidium with the scientific name of Psidium guajava (PG) (Taylor 2013). In Malaysia, it is traditionally used for dermatosis, diarrhoea, epilepsy, hysteria and menstrual disorders (Taylor 2013). Its fruit contains high content of vitamin A and C, crude fibers, carbohydrates, protein, fat, moisture, ash and minerals (Lim et al.2006). The PG possesses antioxidant effect (Kriengsak et al. 2006), free radical scavenging activity (Hui \& Gow 2007), antidiabetic (Oh et al.2005), antibacterial (Nwinyi et al.2008) and hepatoprotective effects (Roy et al. 2006). Polysaccharides from fruits and vegetables have free 
radical scavenging activity which is in relation with its chemical properties and characteristics (Kriengsak et al. 2006). Moreover, the polysaccharides from herbal origin have been shown to possess hepatoprotective effect (Liping et al. 2012; Wang et al. 2012).

Toxic dose ingestion of paracetamol (PCM) can cause liver damage, leading to liver failure as liver is an organ to detoxify endogenous and exogenous noxious substances (Cemek et al. 2010). PCM-induced liver injury is due to its toxic metabolites, $\mathrm{N}$-acetyl-p-benzoquinone imines (NAPQI), which are normally detoxified by hepatic glutathione (GSH) (James et al. 2003). In PCM overdose, the amount of toxic metabolites exceeds the detoxification capacity of GSH that initiates the binding of these metabolites to cellular proteins, resulting in cell injury (Ward \& William 1999). Reactive oxygen species (ROS) are produced during PCM metabolism in the liver. Therefore, oxidative stress might attribute the cell injury in PCM-induced liver injury (Dart et al. 2006). Inflammation is a body response to tissue injury. PCM toxicity stimulates Kupffer cells in the liver (Laskin et al. 1995). Activated Kupffer cell stimulates the formation of pro-inflammatory and anti-inflammatory cytokines which have important roles in immunity, inflammation, cell proliferation, differentiation and cell death (Shen \& Pervaiz 2006). Therefore, the present study was aimed to determine the effect of polysaccharides from Psidium guajava fruit (PPG) supplementation on the antioxidant and inflammatory cytokine changes following PCMinduced liver toxicity. It will be beneficial to develop a dietary supplementation to prevent liver injury from potential hepatotoxic drugs.

\section{MATERIALS AND METHODS}

\section{EXTRACTION OF POLYSACCHARIDE FROM PSIDIUM GUAJAVA FRUIT}

Guava fruits were purchased from Sime Darby Beverages Sdn Bhd, Perak, Malaysia. The details of the fruits were noted, authenticated and stored its voucher specimen (UKMB: 40068) in the Herbarium of Universiti Kebangsaan Malaysia (UKM). The dried ground guava fruits were extracted five times in boiling water for $2 \mathrm{~h}$. The extract was then collected, filtered and concentrated under reduced pressure. The concentrated extract was centrifuged at $4000 \mathrm{rpm}$ for $10 \mathrm{~min}$ and the supernatant was collected for further processing. The $95 \%$ ethanol was added to the supernatant to extract the water soluble polysaccharide solution. Then, the Sevag reagent was added to the solution to remove protein and finally the resultant solution was freeze-dried (Park et al. 2000).

\section{ANIMAL HANDLING}

Thirty eight ( $n=38$ ) male Sprague-Dawley rats (200-300 g) were purchased from the Sapphire Enterprise Animal House, Sri Kembangan, Selangor, Malaysia. The rats were kept at room temperature $\left(23-32^{\circ} \mathrm{C}\right)$ with $12 \mathrm{~h}$ light/dark photoperiod in the animal laboratory of the Anatomy Department, Faculty of Medicine, UKM. The rats were given standard rat chow (Gold Coin, Malaysia) and tap water ad libitum. The handling of animals was in accordance with the experimental protocol approved by the animal ethical committee of the University (FP/ANAT/2012/ FARIDA/18-JULY/451-JULY-2012-SEPTEMBER-2013). The project approval was obtained from the Research Committee, Faculty of Medicine, UKM (FF-353-2012). Animal welfare was monitored daily in terms of body weight, general behaviour and physical activities.

\section{EXPERIMENTAL DETAILS}

After one week of acclimatisation, the animals were randomly divided into two groups: Control and paracetamol (PCM) induction groups. The control group $(n=14)$ was subdivided into control without treatment (group C) and control with treatment (group PPG400). The animals in these groups received $4 \mathrm{~mL}$ of $0.9 \%$ normal saline (NS) and $400 \mathrm{mg} / \mathrm{kg}$ of polysaccharides (PPG) per oral, respectively, for fourteen days. At day 15, the animals were given 5\% dimethyl sulfoxide (DMSO). The animals in PCM groups were further divided into PCM without treatment (group PCM), PCM with low dose PPG (group PPG200+PCM) and PCM with high dose PPG (group PPG400+PCM). The respective groups received $0.9 \% \mathrm{NS}, 200 \mathrm{mg} / \mathrm{kg}$ of PPG and $400 \mathrm{mg} / \mathrm{kg}$ of PPG for fourteen days. At day 15, the PCM (2 $\mathrm{g} / \mathrm{kg}$ ) was given orally. After $24 \mathrm{~h}$ of PCM induction, all the experimental animals were sacrificed. The blood sample and the liver tissue were collected for biochemical and histological analysis.

\section{BIOCHEMICAL ANALYSIS}

The serum sample was sent to the Pathology laboratory to determine the level of alanine transaminase (ALT) and aspartate transaminase (AST). The hepatic tissue was kept in $-80^{\circ} \mathrm{C}$ for determination of superoxide dismutase (SOD), gluthathione (GSH), tumor necrosis factor alpha (TNF- $\alpha$ ) and interleukin 6 (IL-6). The SOD, GSH, TNF- $\alpha$ and IL- 6 were measured using specific enzyme-linked immunosorbent assay (ELISA) kits.

\section{PREPARATION AND MEASUREMENT OF SUPEROXIDE DISMUTASE (SOD)}

The liver tissue was rinsed in phosphate buffered saline (PBS), $\mathrm{pH} 7.4$, to remove red blood cells and clots. The tissue was homogenised in $5-10 \mathrm{~mL}$ of cold $20 \mathrm{mM}$ of 4-2-hydroxyethyl-1-piperazine ethane sulfonic acid (HEPES) buffer (pH7.2), containing $1 \mathrm{mM}$ of ethylene glycol tetraacetic acid (EGTA), $210 \mathrm{mM}$ mannitol and $70 \mathrm{mM}$ sucrose per gram tissue. The liver tissue was centrifuged at $1500 \times \mathrm{g}$ at $4^{\circ} \mathrm{C}$ for $5 \mathrm{~min}$. Then, the supernatant was stored at $-80^{\circ} \mathrm{C}$. Cayman's Superoxide Dismutase Assay Kit (Cayman, USA) utilises a tetrazolium salt for detection of superoxide radicals generated by 
xanthine oxidase and hypoxanthine. One unit of SOD was defined as the amount of enzyme needed to exhibit $50 \%$ dismutation of superoxide radical.

\section{PREPARATION AND MEASUREMENT OF GLUTHATHIONE (GSH)}

Liver was rinsed with PBS solution ( $\mathrm{pH} 7.4)$ to remove red blood cells and clots. The liver tissue was homogenised in 5-10 mL of cold $50 \mathrm{mM}$ of $\mathrm{N}$-morpholino ethane sulfonic acid (MES) or phosphate buffer (pH6-7), containing $1 \mathrm{mM}$ of ethylene diamine tetraacetic acid (EDTA) per gram tissue. The tissue was centrifuged at $10000 \times \mathrm{g}$ for $15 \mathrm{~min}$ at $4^{\circ} \mathrm{C}$. The supernatant was removed and stored at $-20^{\circ} \mathrm{C}$. The supernatant was deproteinated before assaying. The MPA reagent was prepared by dissolving $5 \mathrm{~g}$ of metaphosphoric acid (Sigma-Aldrich 239275) in $50 \mathrm{~mL}$ of water. The MPA reagent was added to the sample and mixed by vortexing. The mixture was allowed to stand at room temperature for $5 \mathrm{~min}$ and centrifuged at more than $2000 \mathrm{~g}$ for at least $2 \mathrm{~min}$. Then, the supernatant was collected carefully and stored at $-20^{\circ} \mathrm{C}$. The triethanolamine (TEAM) $(531 \mu \mathrm{L}$ TEAM in $469 \mu \mathrm{L}$ of water) reagent was added to the supernatant (50 $\mu \mathrm{L}$ of TEAM reagent per $\mathrm{mL}$ of the supernatant) for the GSH assay.

Cayman's GSH assay (Cayman, USA) utilises a carefully optimized enzymatic recycling method, using gluthathione reductase for the quantification of GSH. The sulfhydryl group of GSH reacted with 5,5'-dithio-bis-2-(nitrobenzoic acid) (DTNB) and a colored 5-thio-2-nitrobenzoic acid (TNB). The mixed disulfide, GSTNB (between GSH and TNB) was reduced by gluthathione reductase to recycle the GSH and produce more TNB. The rate of TNB production was directly proportional to the concentration of GSH in the sample. The measurement of the absorbance of TNB at 405-414 nm provided an accurate estimation of GSH in the sample.

\section{PREPARATION AND MEASUREMENT OF TUMOUR NECROSIS FACTOR ALPHA (TNF- $\alpha)$}

Liver tissue was rinsed in ice-cold PBS $(0.02 \mathrm{~mol} / \mathrm{L}$, $\mathrm{pH} 7.0-7.2)$ to remove excess blood. The tissue was homogenised in 5-10 mL of PBS with glass homogeniser on ice (Micro Tissue Grinders woks). Two freeze-thaw cycles were performed to break the cell membranes. Then, the homogenates were centrifuged at $5000 \times \mathrm{g}$ for $5 \mathrm{~min}$. The supernatant was removed and stored at $-80^{\circ} \mathrm{C}$.

The standards and samples were then added to the appropriate microtitre plate pre-coated with TNF- $\alpha$ antibody (USCNK, USA). Then, avidin conjugated with 35 horseradish peroxidase (HRP) was added to each microplate well and then the plate was incubated. After $3,3^{\prime}, 5,5^{\prime}$-tetramethylbenzidine (TMB) substrate solution was added only to those wells which contained TNF- $\alpha$ and biotin-conjugated antibody. The enzymesubstrate reaction was terminated by adding sulphuric acid solution and the colour change was measured spectrophotometrically at a wavelength of $450 \mathrm{~nm}$. The concentration of TNF- $\alpha$ in the samples was then determined by comparing the optical density (O.D) of the samples and standard curve.

\section{PREPARATION AND MEASUREMENT OF INTERLEUKIN 6 (IL-6)}

The $100 \mathrm{mg}$ liver tissue was rinsed with PBS, homogenised in $1 \mathrm{~mL}$ of PBS and stored overnight at $-20^{\circ} \mathrm{C}$. After two freeze-thaw cycles were performed to break the cell membranes, the homogenates were centrifuged at $5000 \times$ $\mathrm{g}\left(2-8^{\circ} \mathrm{C}\right)$ for $5 \mathrm{~min}$. The supernatant was stored at $-80^{\circ} \mathrm{C}$. This IL- 6 assay (Cusabio, USA) employed the quantitative sandwich enzyme immunoassay technique. The standards and samples were pipetted into the wells precoated with IL- 6 antibody and the IL- 6 in the sample was bound with immobilized antibody. After removing the unbound substances, a biotin-conjugated antibody specific for IL-6 was added to the wells. After washing, avidin conjugated HRP was added. Following a wash to remove unbound avidin-enzyme reagent, a substrate solution was added to develop the colour in proportion to the amount of IL-6 bound in the initial step. The colour development was stopped and intensity of the colour was measured.

\section{HISTOLOGICAL EVALUATION OF THE LIVER}

The formalin fixed tissue sections from the differents groups were stained with haematoxylin and eosin (H\&E). The periodic acid Schiff (PAS) stain was used to detect hepatic glycogen.

\section{STATISTICAL ANALYSIS}

The data were expressed as mean \pm standard error mean (SEM) and statistical analysis was performed using one-way analysis of variance (ANOVA) followed by post hoc test (Benferroni). The $p$ value less than 0.05 was considered as statistical significant. The SPSS programme version 21 (SPSS Inc. Chicago, IL, USA) was used to analyse the data.

\section{RESULTS}

\section{BODY WEIGHT}

The body weight of rats in all groups significantly increased from Day 1 to Day 15 which indicated the PPG supplementation had no side effect. $24 \mathrm{~h}$ after the PCM induction, it was observed the significant reduction of body weight in PCM, PPG200+ PCM and PPG400+ PCM $(p<0.05)$ (Figure 1). This drastic weight drop might be owing to the toxic effect of PCM.

\section{CHANGES OF LIVER ENZYMES}

The mean AST and ALT levels in all groups were shown in Figure 2. The AST and ALT levels were significantly higher in the group PCM compared with control group $(p<0.05)$ which confirmed the PCM-induced hepatocyte injury. The high dose PPG supplemented (PPG400+ PCM) group 


\section{Body weight changes}

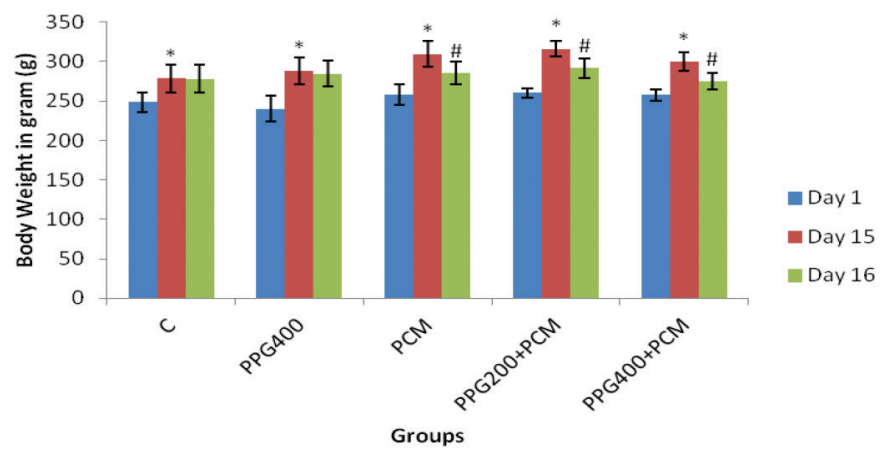

FIGURE 1. Mean body weight of experimental animals at Day 1 (before PPG supplementation), Day 15 (before PCM induction) and Day 16 (24 h after the PCM induction). *indicates significant difference compared with Day 1 between Day 15. \#indicates significant difference compared with Day 15 between Day 16
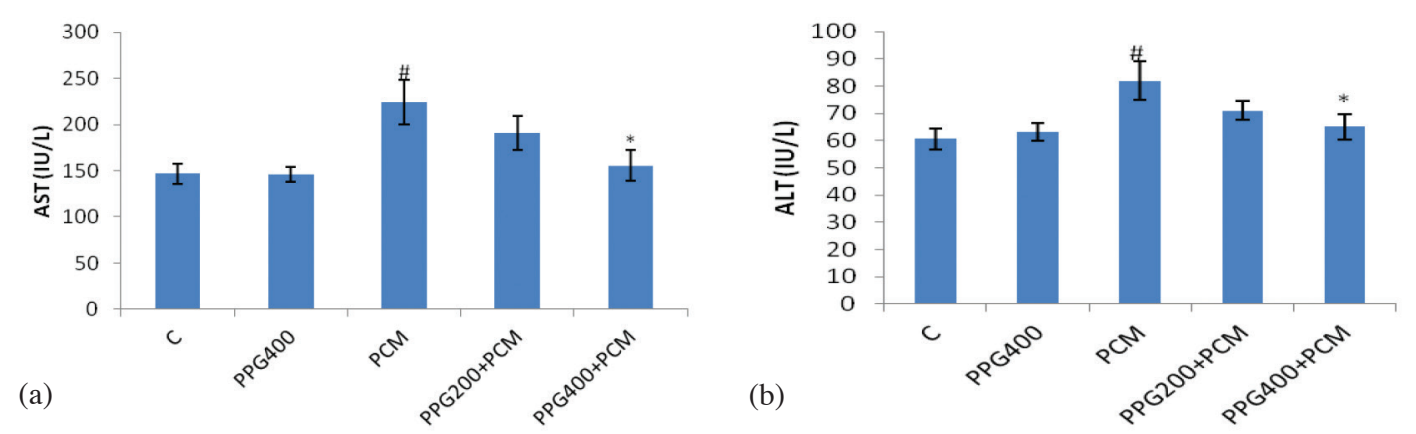

FIGURE 2. a) Mean levels of Aspartate transaminase (AST) and b) Alanine transaminase (ALT) at day 16. "indicates significant difference compared with C and PPG400. *indicates significant difference compared to PCM group $(p<0.05)$

showed significant lower level of AST and ALT following PCM induction $(p<0.05)$. This result proved the PPG had the hepatoprotective effect.

\section{CHANGES OF INNATE ANTIOXIDANTS}

Hepatic SOD activity and GSH level were significantly reduced in the PCM group compared with group C $(p<0.05)$. Our result showed the PCM-induction attributed the depletion of endogenous antioxidants. The SOD activity was significantly increased in the PPG treated groups (PPG200+PCM and PPG400+PCM) (Figure 3(a)) compared with PCM group. The GSH level was significantly higher in the PPG400 and PPG400+PCM groups compared with PCM group. The GSH level in the PPG400 group was significantly higher than group C (Figure 3(b)). Therefore, the PPG supplementation maintained the antioxidant activity.

\section{CHANGES OF INFLAMMATORY MARKERS}

The TNF- $\alpha$ level was significantly increased in the PCM group compared with group $\mathrm{C}(p<0.05)$. This might be a consequence of Kupffer cells activation following cells injury. The TNF- $\alpha$ level in the PPG400 group was
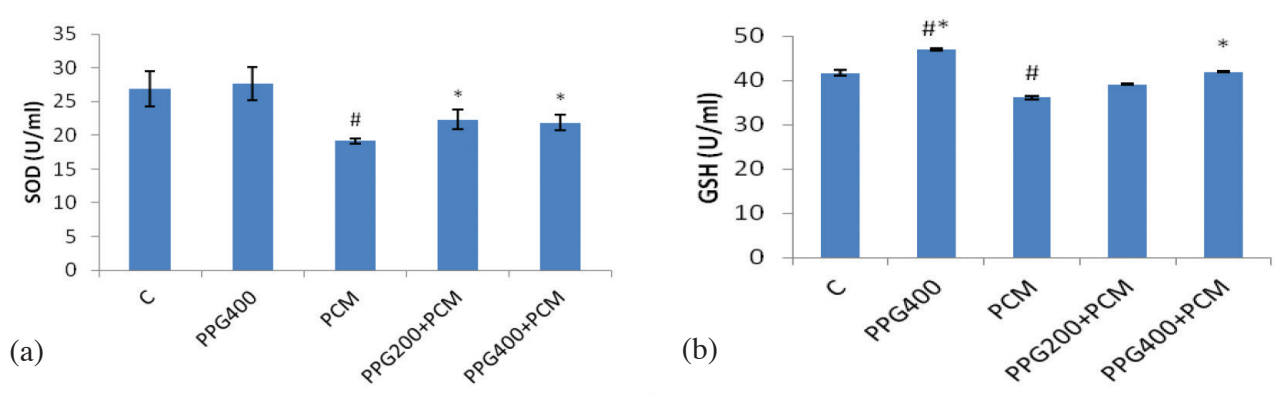

FIGURE 3. a) Superoxide dismutase (SOD) activity and b) Glutathione (GSH) level at day 16. "indicates significant difference compared with $\mathrm{C}$ group $(p<0.05)$. *indicates significant difference compared with PCM group $(p<0.05)$ 
significantly higher compared with group C. However, the TNF- $\alpha$ level in PPG400 group was significantly lower than PCM group $(p<0.05)$. The PPG400+PCM group showed significant decreased level of TNF- $\alpha$ compared with PCM group (Figure 4(a)). This result showed the PPG suppressed the TNF- $\alpha$ release from the activated Kupffer cells in PCM-induced liver injury, although it enhanced the TNF- $\alpha$ level in the normal rats. The mean level of IL- 6 in all groups was shown in Figure 4(b). The hepatic IL-6 level was significantly increased in the PCM group as compared with the control group $(p<0.05)$ which showed there was an inflammatory reaction in the PCM group. However, the IL6 levels were reduced in the PPG supplemented groups as dose-dependent manner.

\section{MICROSCOPIC CHANGES}

Group C and group PPG400 showed radiating hepatocellular cords from the central vein to the portal triad and the sinusoidal spaces were present in between the cellular cords (Figure 5(a) \& 5(b)). The PCM group showed vacuolisation in hepatocytes, loss of cell boundaries, inflammatory cells infiltration and distorted hepatocelluar cords which resulted in narrow sinusoidal spaces (Figure 5(c)). However, the animals pre-treated with PPG exhibited liver histology which was comparable with the control groups (Figure 5(d) $\& 5(\mathrm{e}))$. Glycogen storage is one of the functions of liver. Glycogen depletion could be encountered in any kind of liver injury. The glycogen was detected in the liver tissue of group C and group PPG400 (Figure 6(a) \& 6(b)). Glycogen depletion was found in group PCM (Figure 6(c)). The PPG supplemented groups showed a large amount of glycogen deposition even with PCM induction (Figure 6(d) \& 6(e)) These results showed that the PPG supplementation not only maintained the cellular architecture but also reserved the functional integrity of the liver.

\section{DISCUSSION}

Body weight reduction is one of the presenting features in drug-induced liver injury (O'Brien et al. 2000) and the significant body weight reduction was found following the PCM induction in the present study. The body weight reduction might be owing to impaired liver function as one of its functions is to breakdown the nutrients and release into the blood stream. Supplementation with hepatoprotective drugs might maintain or lessen the
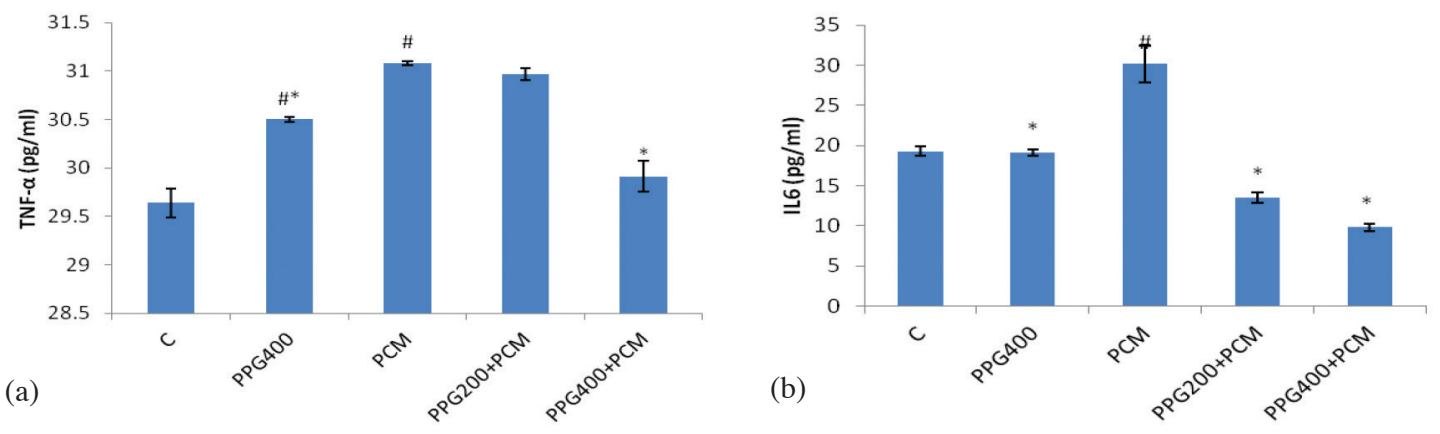

FIGURE 4. a) Mean levels of tumour necrosis factor- $\alpha$ (TNF- $\alpha$ ) and b) Interleukin 6 (IL6) at Day 16. "indicates significant difference compared with C $(p<0.05)$. *Indicates significant difference compared with PCM $(p<0.05)$

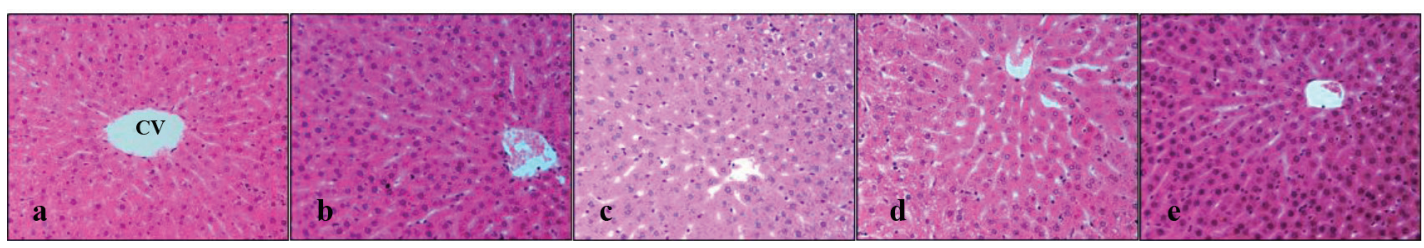

FIGURE 5. Histological features of liver tissue (X200; H\&E stain): a) group C; b) group PPG400; c) group PCM; d) group PPG200+PCM and e) group PPG400+PCM. CV: central vein

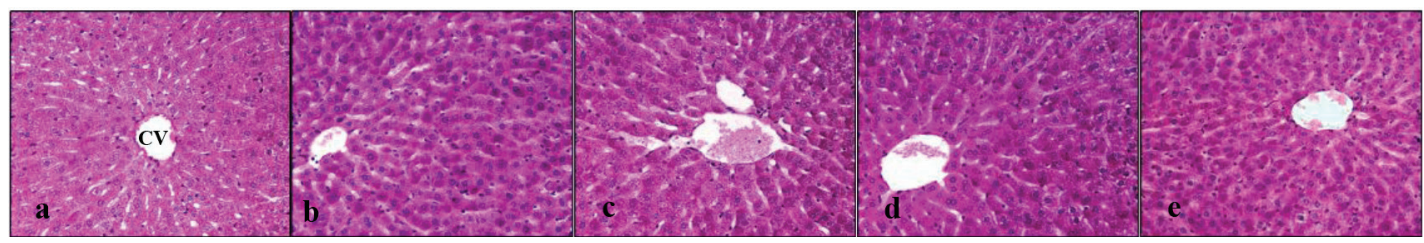

FIGURE 6. Glycogen content in liver tissue (X200; PAS stain): a) group C; b) group PPG400; c) group PCM; d) group PPG200+PCM and e) group PPG400+PCM. CV-central vein 
extent of body weight reduction (Anantha et al. 2012). Sometimes, it may even increase the body weight (Gupta \& Flora 2006). In the present study, the supplementation of PPG did not seem to prevent the body weight reduction following PCM-induction.

Acute hepatitis and/or cholestasis are usual presentations in drug-induced hepatotoxicity (Kaplowitz 2004). The high level of liver enzymes in the serum will be detected in acute liver injury. This is because various cytosolic enzymes from hepatocytes are released into blood stream due to cell membrane damage (Yanpallewar et al. 2002). Alanine transaminase (ALT) is a liver specific enzyme and its elevation indicates the cellular leakage and loss of functional integrity of the cell membrane (Subramoniam \& Pushpagada 1999). The elevated aspartate transaminase (AST) and alkaline phosphatase (AP) could also be detected. The elevated liver enzyme in the PCM group of the present study confirmed hepatocytes damage. The elevated serum transaminases level returns to normal when the liver cells undergo healing and regeneration (Anusha et al. 2011). In the present study, the PPG supplemented groups showed lower level of liver enzymes. Therefore, the PPG supplementation is able to maintain the cell membrane integrity.

In paracetamol (PCM) overdose, toxic metabolites (NAPQIs) are excessively formed by the action of cytochrome P450 enzymes, leading to glutathione (GSH) depletion (James et al. 2003). The GSH depletion was found in the PCM group of the present study. When the GSH is depleted, the unconjugated toxic NAPQIs may bind to cellular protein, resulting in apoptosis and necrosis (Jame et al. 2003). The microscopic features of PCMinduced liver injury include swelling of hepatocytes, vacuolisation of cells, aggregated hepatocytes and cellular necrosis around central vein, narrowing of sinusoidal spaces and inflammatory cell infiltration (Roy et al. 2006). Furthermore, glycogen depletion is one of the signs of liver injury. The histological findings in the PCM group of the present study was similar to those described by Roy et al. (2006). In addition, glycogen depletion was observed in the PCM group. However, the PPG supplemented groups showed the histological features which were similar to those of the normal control (C) group. This result indicated that PPG supplementation had potential protective effect. Oxidative stress is one of the contributing factors in PCMinduced liver injury (Reid et al. 2005). The superoxide dismutase (SOD) and GSH are parts of innate antioxidant system. The insufficiency of antioxidants result in cellular damage. The SOD plays a crucial role in cellular defense against reactive oxygen species (ROS) (Li et al. 2010). The SOD neutralizes ROS to less toxic hydrogen peroxide $\left(\mathrm{H}_{2} \mathrm{O}_{2}\right)$ (Ding et al. 2012). The impaired SOD activity was observed in the PCM group of the present study, resulting in accumulation of ROS which initiated the oxidative stressinduced tissue damage. However, the PPG supplementation was able to maintain the SOD activity. It has been proven that the polysaccharides from herbal sources protect the liver injury by enhancing the SOD activity (Gan et al. 2012; Liang et al. 2011).
The GSH is an endogenous antioxidant and a basic unit in glutathione peroxidase which is essential for the removal of $\mathrm{H}_{2} \mathrm{O}_{2}$ (Lobo et al. 2010). The GSH depletion in PCMinduced toxicity may weaken the glutathione peroxidase activity, resulting in accumulation of $\mathrm{H}_{2} \mathrm{O}_{2}$ which may further enhance the oxidative stress in PCM-induced rats (Malik et al. 2013). However, the PPG supplementation was able to increase the GSH level not only in PCM-induced groups but also in the normal group. Our findings indicated that the PPG supplementation is able to promote the endogenous GSH formation.

Inflammation occurs as a consequence of tissue injury. The inflammatory cytokines are released as part of the healing process. The tumour necrosis factor alpha (TNF- $\alpha$ ) and interleukin-6 (IL-6) are released following the injury in order to maintain the liver function and enhance the regeneration capacity of liver tissue (Michalopoulos 2007). In our study, the increased TNF- $\alpha$ and IL-6 levels were seen in the PCM group that confirmed the tissue damage due to PCM toxicity. The reduced levels of TNF- $\alpha$ and IL6 was observed in the high dose PPG supplemented group. This findings indicated there was only mild inflammatory reaction occurred in response to lesser extent of tissue injury. Therefore, fourteen day supplementation of PPG attenuated the PCM-induced liver injury.

\section{CONCLUSION}

The PPG supplemented groups showed reduced levels of serum liver enzymes and inflammatory makers. It also showed the increased level of GSH and SOD activity, mild histological changes and the increased glycogen storage. Therefore, we concluded that the PPG supplementation attenuates the PCM-induced liver injury by enhancing the endogenous antioxidant activity. The beneficial effects of PPG can be applied to develop a hepatoprotective dietary supplementation in future.

\section{ACKNOWLEDGEMENTS}

The authors would like to acknowledge the Faculty of Medicine, Universiti Kebangsaan Malaysia for providing the research grant (FF-353-2012), institution animal ethic committee for their guidance, the statisticians, the staff of the Anatomy and Biochemistry Department and the staff of the Forest Research Institute of Malaysia for their technical assistance.

Conflict of interest: None to declare except the product of the current research is under the process of patent filing.

\section{REFERENCES}

Anantha,K.C.,Siva, R.C.\& Manohar, R.A. 2012.Hepatoprotective effect of biherbal ethanolic extract against paracetamolinduced hepatic damage in albino rats. Journal of Ayurveda and Integrative Medicine 3: 198-203.

Anusha, M., Venkateswarlu M., Prabhakaran, V., Shareen Taj, S., Pushpa Kumari, B. \& Ranganayakulu, D. 2011. Hepatoprotective activity of aqueous extract of Portulaca 
oleracea in combination with licopene in rats. Indian Journal of Pharmacology 43(5): 563-567.

Cemek, M., Anmelek, F., Buyukokuroglu, M. \& Karaca, E. 2010. Protective potential of Royal Jelly against carbon chloride induced-toxicity and changes in the serum sialic acid levels. Food and Chemical Toxicology 48: 2827-2832.

Dart, R.C., Erdman, A.R., Olson, K.R., Christianson, G., Manoguerra, A.S., Chyka, P.A., Caravati, E.M., Wax, P.M., Keyes, D.C., Woolf, A.D., Scharman, E.J., Booze, L.L. \& Troutman, W.G. 2006. Acetaminophen poisoning: An evidence-based consensus guideline for out-of-hospital management. Clinical Toxicology 44: 1-18.

Ding, L.L., Zhang, B.F., Dou, W., Yang, L., Zhan, C.S. \& Wang, Z.T. 2012. Protective effect of Danning tablet on acute liver injury with cholestasis induced by alphanaphthylsothiocyanate in rats. Journal of Ethnopharmacology 140: $222-229$

Gan, D., Ma, L., Jiang, C., Wang, M. \& Zeng, X. 2012. Medium optimization and potential hepatoprotective effect of mycelial polysaccharides from Pholiota dinghuensis $\mathrm{Bi}$ against carbon tetrachloride-induced acute liver injury in mice. Food Chemical Toxicology 50(8): 2681-2688.

Gupta, R. \& Flora, S.J.S. 2006. Effect of Centella asiatica on arsenic induced oxidative stress and metal distribution in rats. Journal of Applied Toxicology 26(3): 213-222.

Hui, Y.C. \& Gow, C.Y. 2007. Antioxidant activity and free radicalscavenging capacity of extracts from guava (Psidium guajava L.) leaves. Food Chemistry 101: 686-694

James,L.P.,Philip, R. \& Hinson, A. 2003. Acetaminophen-induced hepatotoxicity. The American Society and Phamacology and Experimental Therapeutics 31: 1499-1505.

Kaplowitz, N. 2004. Drug-induced liver injury. Clinical Infectious Diseases 38: 44-48.

Kriengsak, T., Boonprakob, U., Crosby, K., Cisneros-Zevallos, L. \& Byrne, D.H. 2006. Comparison of ABTS, DPPH, Frap, and ORAC assays for estimating antioxidant activity from guava fruit extracts. Journal of Food Composition and Analysis 19: 669-675.

Laskin, D.L., Gardner, C.R., Price, V.F. \& Jollow, D.J. 1995. Modulation of macrophage functioning abrogates the acute hepatotoxicity of acetaminophen. Hepatology 21: 1045-1050.

Li, Y.G., Ji, D.F., Zhong, S., Shi, L.G., Hu, G.Y. \& Chen, S. 2010. Saponins from Panax japonicas protect against alcohol-induced hepatic injury in mice by up-regulating the expression of GPX3, SOD1 and SOD3. Alcohol and Alcoholism 45: 320-331.

Liang, D., Zhou, Q., Gong, W., Wang, Y., Nie, Z., He, H., Li, J., Wu, J., Wu, C. \& Zhang, J. 2011. Studies on the antioxidant and hepatoprotective activities of polysaccharides from Talinum triangulare. Journal of Ethnopharmacology 136(2): 316-321.

Lim, Y.Y., Lim, T.T. \& Tee, J.J. 2006. Antioxidant properties of guava fruit: Comparison with some local fruits. Sunway Academic Journal 3: 9-20.

Liping, M., Dan, G., Mingchun, W.,Zhang, Z., Jiang, C.\& Zeng, X. 2012. Optimization of extraction, preliminary characterization and hepatoprotective effects of polysaccharides from Starchys foridana Schuttl. ex. Benth. Carbohydrate Polymers 87(2): 1390-1398.

Lobo, V., Patil,A., Phatak,A.\& Chandra, N. 2010. Free radicals, antioxidants and functional foods: Impact on human health. Pharmacognosy Review 4: 118-126.
Malik,T.,Pandey,D.K.\& Dogra, N. 2013. Ameliorative potential of aqueous root extract of Withania somnifera against paracetamol induced liver damage in mice. Pharmacologia 4: 89-94.

Michalopoulos, G.K. 2007. Liver regeneration. Journal of Cellular Physiology 213(2): 286-300.

Nwinyi, O.C., Chinedu, N.S. \& Ajani, O.O. 2008. Evaluation of antibacterial activity of Psidium guajava and Gongronema Latifolium. Journal of Medical Plants Research 2: 189-192.

O'Brien, P.J., Slaughter, M.R., Swain, A., Birmingham, J.M., Greenhill, R.W., Elcock, F. \& Bugelski, P.J. 2000. Repeated acetaminophen dosing in rats: Adaptation of hepatic antioxidant system. Human and Experimental Toxicology 19(5): 277-283.

Oh, W.K., Lee, C.H., Lee, M.S., Bae, E.Y., Sohn, C.B., Oh, H., Kim, B.Y. \& Ahn, J.S. 2005. Antidiabetic effects of extracts from Psidium guajava. Journal of Ethnopharmacology 96(3): 411-415.

Park, E.J., Nan, J.X., Kim, J.Y., Kang, H.C., Choi, J.H., Lee, S.J., Lee, B.H., Kim, S.J., Lee, J.H., Kim, Y.C. \& Sohn, D.W. 2000. The ethanol-soluble part of a hot-water extract from Artemisia iwayomogi inhibits liver fibrosis induced by carbon tetrachloride in rats. Journal of Pharmacy and Pharmacology 52(7): 875-881

Reid, A.B., Kurten, R.C., McCullough, S.S., Brock, R.W. \& Hinson, J.A. 2005. Mechanisms of acetaminophen-induced hepatotoxicity: Role of oxidative stress and mitochondrial permeability transition in freshly isolated mouse hepatocytes. The Journal of Pharmacology and Experimental Therapeutics 312(2): 509-516

Roy, C.K., Kamath, J.V. \& Asad, M. 2006. Hepatoprotective activity of Psidium guajava L. leaf extract, Indian. Journal of Experimental Biology 44: 305-311.

Shen, H.M. \& Pervaiz, S. 2006. TNF receptor superfamilyinduced cell death: Redox-dependent execution. The Journal of the Federation of American Societies for Experimental Biology 20: 1589-1598.

Subramoniam, A. \& Pushpagada, P. 1999. Development of phytomedicines for liver diseases. Indian Journal of Pharmacology 31: 166-175.

Taylor, L. 2013. Tropical Plant Database. http://www.rain-tree. com/guava.htm. Accessed on 21 March 2014.

Wang, D., Zhao, Y., Jiao, Y., Yu, L., Yang, S. \& Yang, X. 2012. Antioxidative and hepatoprotective effects of polysaccharides from Zizyphus jujube cv. Shaanbeitanzao. Carbohydrate Polymers 88(4): 1453-1459.

Ward, B. \& Williams, J.M.A. 1999. Paracetamol revisited: A review of the pharmacokinetics and pharmacodynamics. Acute Pain 2: 139-149.

Yanpallewar, S.U., Sen, S., Tapas, S., Mohan Kumar, Raju, S.S. \& Acharya, S.B. 2002. Effect of Azadirachta indica on paracetamol-induced hepatic damage in albino rats. Phytomedicine 10(5): 391-396.

Aspalilah Alias, Faizah Othman, Aqilah Kamaruddin,

Rafizul Yusof \& Farida Hussan*

Department of Anatomy, Faculty of Medicine

Universiti Kebangsaan Malaysia

Jalan Yaacob Latif, Bandar Tun Razak

56000 Cheras, Kuala Lumpur

Malaysia 
Abdul Rashid Li

Forest Research Institute Malaysia (FRIM)

52109 Kepong, Kuala Lumpur

Malaysia
*Corresponding author; email: khinpapah@gmail.com

Received: 27 May 2014

Accepted: 6 April 2015 